\title{
Peningkatan Sensitivitas Dua Kali Uji Tuberkulin untuk Mendeteksi Infeksi Tuberkulosis pada Anak dengan Penyakit Keganasan
}

\author{
Arismunanto Kurniawan, ${ }^{*}$ Fifi Sofiah, ${ }^{*}$ Dian Puspita Sari, ${ }^{*}$ Yuwono** \\ *Departemen Ilmu Kesehatan Anak, **Unit Penelitian Kedokteran Kesehatan Fakultas Kedokteran Universitas Sriwijaya/ \\ RS Moh. Hoesin, Palembang
}

\begin{abstract}
Latar belakang. Pasien imunokompromais lebih berisiko terinfeksi kuman Mycobacterium tuberculosis. Sensitivitas uji tuberkulin pada pasien anak dengan keganasan berkurang karena penurunan Thelper 1 (Th 1). Diperlukan dua kali uji tuberkulin untuk meningkatkan sensitivitas uji tuberkulin pada anak dengan keganasan.

Tujuan. Mengetahui penggunaan dua kali uji tuberkulin lebih sensitif mendeteksi infeksi tuberkulosis pada anak dengan keganasan dibandingkan satu kali uji tuberkulin.

Metode. Penelitian cross sectional dilakukan Juli 2016 sampai 31 Maret 2017 pada pasien anak yang baru terdiagnosis penyakit keganasan usia 6 bulan sampai 18 tahun di Rumah Sakit Dr. M. Hoesin (RSMH). Uji tuberkulin dilakukan pada semua subjek. Anak dengan hasil uji tuberkulin negatif saat uji tuberkulin pertama dilakukan uji tuberkulin kedua setelah 2 sampai 4 minggu uji tuberkulin pertama. Hasil positif bila indurasi $\geq 5 \mathrm{~mm}$.

Hasil. Lima puluh pasien anak dengan keganasan ikut dalam penelitian. Tigapuluh dua subjek laki-laki dan 18 perempuan. Jenis penyakit keganasan terbanyak adalah leukemia limfoblastik akut 27 (54\%). Pada uji tuberkulin pertama didapatkan hasil positif pada 4 subjek dan pada uji tuberkulin kedua didapatkan hasil positif pada 7 subjek. Terdapat perbedaan signifikan $(\mathrm{p}<0,001)$ antara indurasi hasil uji tuberkulin pertama dan kedua. Terdapat peningkatan sensitivitas dua kali uji tuberkulin dibandingkan satu kali uji tuberkulin. Kesimpulan. Penggunaan dua kali uji tuberkulin pada anak dengan keganasan lebih sensitif untuk mendeteksi infeksi tuberkulosis dibandingkan satu kali uji tuberkulin. Sari Pediatri 2018;19(5):245-51
\end{abstract}

Kata kunci: dua kali uji tuberkulin, penyakit keganasan, sensitivitas

\section{Increased Sensitivity of Two-Step Tuberculin Test to Detect Tuberculosis Infection in Children with Malignant Disease}

\begin{abstract}
Arismunanto Kurniawan, ${ }^{*}$ Fifi Sofiah, ${ }^{*}$ Dian Puspita Sari, ${ }^{*}$ Yuwono**
Background. Immunocompromised patients are at greater risk of infection with Mycobacterium tuberculosis germs. The sensitivity of tuberculin test in pediatric patients with malignancy was reduced by the decrease in helper $\mathrm{T} 1$. It takes twice the tuberculin test to increase the sensitivity of tuberculin test in children with malignancy. ${ }^{1}$

Objective. Knowing the use of two-step tuberculin test is more sensitive to detect tuberculosis infection in children with malignancy than once a tuberculin test

Methods. A cross sectional study was conducted July 2016 to March 31, 2017 in pediatric patients newly diagnosed with malignant disease, aged 6 months to 18 years at Dr. Hospital. M. Hoesin. The tuberculin test is performed on all subjects. Children with negative tuberculin test results at the first tuberculin test, a second tuberculin test was performed after 2 to 4 weeks of first tuberculin test. Positive results if induration $\geq 5 \mathrm{~mm}$.

Result. Fifty pediatric patients with malignancy participated in the study. A total of 32 male subjects, 18 female subjects. The most common type of malignancy is acute lymphoblastic leukemia of 27 (54\%). There were 4 subjects with positive results in the first tuberculin test and 7 subjects positive result with two-step tuberculin test. There were significant differences $(\mathrm{p}<0.001)$ between induration of first and second tuberculin test results. There was an increase in the sensitivity of two-step tuberculin tests compared with one tuberculin test.

Conclusion. The use of two-step tuberculin test in children with malignant disease is more sensitive to detect tuberculosis infection
\end{abstract} compared to one tuberculin test. Sari Pediatri 2018;19(5):245-51

Keywords: two-step tuberculin test, child, malignancy, sensitivity

Alamat korespondensi: Dr. Fifi Sofiah, SpA(K), Dr. Arismunanto Kurniawan. Departemen Ilmu Kesehatan Anak FK Universitas Sriwijaya / RS Mohammad Heosin Palembang. Jl. Jenderal Sudirman Km 3,5,30216. Email: arisdr_81@yahoo.com 
A

ngka prevalensi tuberkulosis (TB) pada

anak diperkirakan sekitar 500.000 setiap

tahunnya dengan angka kematian berkisar

70.000 anak. Di Indonesia, di antara semua kasus TB yang ternotifikasi dalam program TB, proporsi kasus TB anak adalah $8 \%-11 \%$. Pengendalian TB ini juga difokuskan pada kelompok risiko tinggi. ${ }^{2,3}$ Pasien dengan imunokompromais, seperti penyakit keganasan memiliki risiko lebih besar terkena sakit TB saat terinfeksi kuman Mycobacterium tuberculosis (M.tb). Kamboj ${ }^{4}$ dalam penelitiannya menyatakan bahwa risiko terinfeksi TB 50 kali lebih besar pada pasien dengan keganasan.

Deteksi infeksi TB anak dapat digunakan dengan dua metode, yaitu uji tuberkulin dan interferon gamma release assays (IGRA). Faktor imunokompromais dengan keganasan dapat menimbulkan kesulitan tersendiri karena sensitivitas pasien terhadap uji tuberkulin menjadi berkurang. Anak dengan keganasan akan mengalami gangguan sistem imunitas selular yang dimediasi oleh limfosit $\mathrm{T}$. Anak dengan keganasan akan mengalami penurunan sel Th 1 . Peran sel Th 1 dalam hipersensitivitas tipe lambat merupakan reaksi terhadap uji tuberkulin sehingga sensitivitasnya akan berkurang. Pada anak dengan keganasan dibutuhkan uji tuberkulin serial yang dikenal dengan two-step mantoux test, dua kali uji tuberkulin yang dilakukan pada individu yang berisiko terinfeksi TB.

Uji tuberkulin dilakukan dua kali karena adanya kemungkinan hasil negatif palsu akibat berkurangnya reaksi sensitivitas terhadap uji tuberkulin. Sensitivitas uji tuberkulin pada pasien dengan penyakit keganasan yang terinfeksi TB dapat berkurang 20\%. Penelitian yang dilakukan Mohammad $\mathrm{dkk}^{1}$ di Mesir dengan melakukan uji tuberkulin dua kali pada pasien dengan keganasan, didapatkan hasil pasien yang terinfeksi TB dari $4 \%$ menjadi $16 \%$ pada uji tuberkulin yang kedua. ${ }^{1,3,5-7}$

Penelitian mengenai uji tuberkulin yang dilakukan dua kali pada pasien dengan keganasan hematoonkologi untuk mendeteksi infeksi TB belum pernah dilakukan di Indonesia, khususnya di rumah sakit Moh. Hoesin (RSMH), Palembang. Penelitian ini bertujuan untuk mengetahui apakah terdapat perubahan hasil uji tuberkulin dari negatif menjadi positif saat dilakukan uji tuberkulin kedua. Diharapkan, peningkatan sensitivitas penggunaan dua kali uji tuberkulin dapat diketahui apakah lebih baik dibandingkan satu kali uji tuberkulin. ${ }^{8-12}$

\section{Metode}

Penelitian cross sectional dilakukan pada bulan Juli 2016 sampai dengan 31 Maret 2017 pada pasien anak yang baru terdiagnosis penyakit keganasan hemato-onkologi dengan rentang usia 6 bulan sampai dengan 18 tahun di RSMH. Penelitian dilakukan di bangsal Hematologi Anak di RSMH. Seluruh pasien anak dengan keganasan yang memenuhi kriteria inklusi diikutsertakan dalam penelitian. Penelitian ini bertujuan mengetahui apakah penggunaan dua kali uji tuberkulin lebih sensitif dalam mendeteksi infeksi TB pada pasien anak dengan penyakit keganasan.

Sampel adalah seluruh pasien anak yang baru ditegakkan diagnosis keganasan hemato-onkologi yang memenuhi kriteria inklusi. Kriteria inklusi adalah semua pasien laki-laki dan perempuan yang berusia 6 bulan sampai dengan 18 tahun yang baru ditegakkan penyakit keganasan hemato-onkologi yang belum mendapatkan kemoterapi. Kriteria eksklusi pada penelitian ini adalah pasien terdiagnosis TB dan mendapat terapi obat anti TB sebelumnya, pasien dengan HIV, sindrom nefrotik, sistemik lupus eritematosus, dan pasien yang pernah mendapatkan uji tuberkulin dalam jangka waktu 3 bulan sebelumnya.

Seluruh subjek dilakukan identifikasi, pemeriksaan fisis, dan pemeriksaan antropometri. Uji tuberkulin pertama dilakukan pada semua subjek. Uji tuberkulin dengan metode mantoux dilakukan dengan menyuntikkan 0,1 ml PPD RT-23 2TU, secara intrakutan di bagian volar lengan bawah. Hasil uji dibaca dalam 48-72 jam setelah penyuntikan. Keberadaan indurasi ditentukan melalui palpasi, diameter indurasi diukur secara transversal dan ukuran indurasi dalam millimeter. Eritema tidak diperhitungkan. Bila ukuran indurasi didapatkan $\geq 5 \mathrm{~mm}$, dianggap terjadi infeksi TB. Jika ukuran indurasi didapatkan $<5 \mathrm{~mm}$, akan dilakukan uji tuberkulin kedua dengan rentang waktu 2-4 minggu setelah uji tuberkulin pertama. Hasil uji dibaca dalam waktu 48-72 jam. Kemudian dibandingkan ukuran indurasi antara uji tuberkulin pertama dan kedua.

Ukuran indurasi uji tuberkulin pertama dan kedua dilakukan perhitungan rerata. Dari data yang didapatkan dilakukan uji hipotesis dengan statistik $t$ test. Ukuran indurasi uji tuberkulin pertama dibandingkan dengan indurasi pada uji tuberkulin kedua dan dilakukan analisis dengan $t$ test. Penilaian perubahan ukuran indurasi uji tuberkulin pertama dan kedua dianalisis dengan $t$ test. Analisis statistik 
dilakukan dengan menggunakan komputer program SPSS 18. Signifikansi statistik berdasarkan nilai $\mathrm{p}<0,05$ untuk setiap teknik analisis statistik.

Penelitian ini telah mendapat sertifikat persetujuan etik dari Komisi Etik Penelitian Kesehatan RSMH dan Fakultas Kedokteran Universitas Sriwijaya Palembang.

\section{Hasil}

Selama periode penelitian didapatkan 50 subjek yang memenuhi kriteria inklusi. Subjek yang berjenis kelamin laki-laki 32 (64\%) dan perempuan 18 (36\%). Sebagian besar subjek berusia 1-5 tahun dengan jumlah 25 (50\%). Usia termuda adalah 8 bulan dan usia tertua 16 tahun. Jenis penyakit keganasan yang diderita sebagian besar subjek adalah leukemia limfoblastik akut (LLA) 27 (54\%).
Dari hasil penelitian ini didapatkan prevelansi infeksi TB 11 (22\%) subjek dengan 4 nilai positif pada uji tuberkulin pertama dan 7 pada uji tuberkulin kedua. Ukuran indurasi dikatakan hasil positif bila $\geq 5 \mathrm{~mm}$. Uji tuberkulin pertama dilakukan pada 50 subjek dengan nilai positif didapatkan 4 (8\%) subjek dengan ukuran indurasi maksimal $8 \mathrm{~mm}$ (rerata 1,16; SB 1,86). Empat subjek dengan hasil positif pada uji tuberkulin pertama tidak dilakukan uji tuberkulin kedua. Uji tuberkulin kedua didapatkan hasil positif pada 7 (15\%) subjek. Dilakukan t-tes untuk membandingkan indurasi uji tuberkulin pertama pada 11 subjek (4 subjek hasil positif ditambah 7 subjek dengan hasil negatif yang menjadi positif pada uji tuberkulin kedua) dengan indurasi uji tuberkulin kedua pada 7 subjek dengan hasil positif. Dari hasil ttes didapatkan perbedaan signifikan $(p<0,001)$ antara indurasi pertama dan kedua.

Tabel 1. Karakteristik umum subjek penelitian $(\mathrm{n}=50)$

Jumlah (n) Persentase (\%)

\begin{tabular}{|c|c|c|c|}
\hline \multirow[t]{4}{*}{ Usia (tahun) } & $0-1$ & 3 & 6 \\
\hline & $1-5$ & 25 & 50 \\
\hline & $5-10$ & 13 & 26 \\
\hline & $>10$ & 9 & 18 \\
\hline \multirow[t]{2}{*}{ Jenis kelamin } & Laki-laki & 32 & 64 \\
\hline & Perempuan & 18 & 36 \\
\hline \multirow[t]{3}{*}{ Status gizi } & Buruk & 4 & 8 \\
\hline & Kurang & 20 & 40 \\
\hline & Baik & 26 & 52 \\
\hline \multirow[t]{13}{*}{ Jenis penyakit keganasan } & Leukemia limfoblastik akut (LLA) & 27 & 54 \\
\hline & Leukemia mieloblastik akut (LMA) & 3 & 6 \\
\hline & Leukemia myeloid kronik (LMK) & 2 & 4 \\
\hline & Anaplastic large cell lymphoma (ALCL) & 1 & 2 \\
\hline & Germ cell tumor & 3 & 6 \\
\hline & Histiositosis & 1 & 2 \\
\hline & Limfoma Burkitt & 1 & 2 \\
\hline & Non Hodgkin limfoma (NHL) & 3 & 6 \\
\hline & Osteosarkoma & 1 & 2 \\
\hline & Retinoblastoma & 2 & 4 \\
\hline & Teratoma & 1 & 2 \\
\hline & Willm tumor & 1 & 2 \\
\hline & Yolk sac Tumor & 1 & 2 \\
\hline
\end{tabular}


Tabel 2. Ukuran indurasi uji tuberkulin pertama dan kedua

\begin{tabular}{lccc}
\hline Ukuran indurasi & $\mathrm{n}(\%)$ & Rerata & SB \\
\hline $\begin{array}{l}\text { Uji tuberkulin pertama, } \mathrm{mm}(\mathrm{n}=50) \\
\quad 5\end{array}$ & $4(8)$ & & \\
$\quad<5$ & $46(92)$ & & 1,86 \\
Uji tuberkulin kedua, mm (n= 46) & & & \\
$\quad 25$ & $7(15)$ & 1,46 & 2,354 \\
$<5$ & $39(85)$ & & \\
\hline
\end{tabular}

Tabel 3. T-tes membandingkan indurasi awal pada 11 subjek (4 subjek dengan hasil positif pada indurasi awal ditambah 7 subjek hasil positif pada indurasi kedua) dengan indurasi kedua pada 7 subjek dengan hasil positif (indurasi $\geq 5 \mathrm{~mm}$ )

\begin{tabular}{lcccc}
\hline & $\mathrm{n}$ & Rerata & $\mathrm{SB}$ & $\mathrm{p}$ \\
\hline Indurasi awal & 11 & 3,36 & 2,335 & $<0,001$ \\
Indurasi kedua & 7 & 6,00 & 1,915 & \\
\hline
\end{tabular}

Tabel 4. Karakteristik subjek dengan infeksi TB $(\mathrm{n}=11)$

\begin{tabular}{llcc}
\hline & & Jumlah (n) & Persentase (\%) \\
\hline Usia (tahun) & $0-5$ & 5 & 45 \\
& $>5$ & 6 & 55 \\
Jenis kelamin & Laki-laki & 8 & 72 \\
\multirow{5}{*}{ Jenis penyakit keganasan } & Perempuan & 3 & 28 \\
& Hematologi & 7 & 63 \\
Jenis penyakit keganasan & Onkologi & 4 & 37 \\
& Leukemia limfoblastik akut (LLA) & 5 & 45 \\
& Leukemia mieloblastik akut (LMA) & 2 & 18 \\
& Anaplastic large cell lymphoma (ALCL) & 1 & 9 \\
& Germ cell tumor & 2 & 18 \\
Mendapatkan kemoterapi, steroid & Non Hodgkin limfoma (NHL) & 1 & 10 \\
& Ya & 5 & 45 \\
& Tidak & 6 & 55 \\
\hline
\end{tabular}

Dilakukan uji sensitivitas, didapatkan hasil dua kali uji tuberkulin pada pasien keganasan dengan rentang waktu 2-4 minggu akan meningkatkan sensitivitas uji tuberkulin sebesar $175 \%$ dibandingkan dengan satu kali uji tuberkulin dalam mendeteksi infeksi TB.

Terdapat 11 subjek dengan infeksi TB dengan 5 subjek berusia $0-5$ tahun dan 6 subjek berada di rentang usia 5-18 tahun. Delapan subjek laki-laki, 3 subjek perempuan. Tujuh subjek dengan keganasan hematologi, 5 subjek di antaranya adalah LLA. Empat subjek dengan keganasan onkologi. Lima subjek mendapat kemoterapi dan atau steroid. Enam subjek tidak mendapatkan kemoterapi dan steroid.
Pada penelitian ini juga didata mengenai beberapa faktor yang merupakan gejala klinis sakit TB yang dihubungkan dengan angka kejadian infeksi TB pada anak dengan keganasan. Data variabel ini diambil saat awal subjek diikutsertakan dalam penelitian. Beberapa faktor berhubungan dengan infeksi TB di antaranya gambaran radiologis sugestif $\mathrm{TB}$ dengan odds ratio (OR): 22,2 (95\%CI;3,5-141,6), riwayat kontak dengan penderita TB dengan OR: 22,2 (95\%CI;3,5$141,6)$, riwayat demam $\geq 2$ minggu dengan OR: 18,1 (95\%CI;3,6-92,1) riwayat batuk $\geq 3$ minggu dengan OR: 21,0 (95\%CI; 3,8-115,2). Berdasarkan uji statistik didapatkan anak yang memiliki gizi kurang-buruk 
Tabel 5. Beberapa faktor yang berkaitan dengan infeksi TB

\begin{tabular}{|c|c|c|c|c|c|}
\hline \multirow[t]{2}{*}{ Karakteristik } & \multicolumn{2}{|c|}{ Infeksi TB (\%) } & \multirow[t]{2}{*}{ Total (\%) } & \multirow[t]{2}{*}{ OR (CI 95\%) } & \multirow[t]{2}{*}{$\mathrm{p}$} \\
\hline & Infeksi TB & Tidak infeksi TB & & & \\
\hline \multicolumn{6}{|l|}{ Demam $\geq 2$ minggu } \\
\hline Ada & $8(16)$ & $5(10)$ & $13(26)$ & $18,1(3,5-92,1)$ & 0,001 \\
\hline Tidak ada & $3(6)$ & $34(68)$ & $37(74)$ & & \\
\hline \multicolumn{6}{|l|}{ Batuk 3 minggu } \\
\hline Ada & $7(14)$ & $3(6)$ & $10(20)$ & $21(3,8-115,1)$ & 0,001 \\
\hline Tidak ada & $4(8)$ & $36(72)$ & $40(80)$ & & \\
\hline \multicolumn{6}{|l|}{ Status gizi } \\
\hline Kurang- buruk & $7(14)$ & $18(36)$ & $25(50)$ & $2(0,5-8,1)$ & 0,3 \\
\hline Baik & $4(8)$ & $21(42)$ & $25(50)$ & & \\
\hline \multicolumn{6}{|l|}{ Gambaran radiologis } \\
\hline SugestifTB & $6(12)$ & $2(4)$ & $8(16)$ & $22,2(3,5-141,5)$ & 0,001 \\
\hline Tidak sugestif TB & $5(10)$ & $37(74)$ & $42(84)$ & & \\
\hline \multicolumn{6}{|l|}{ Kontak TB } \\
\hline Ada & $6(12)$ & $2(4)$ & $8(16)$ & $22(3,5-141,5)$ & 0,001 \\
\hline Tidak ada & $5(10)$ & $37(74)$ & $42(84)$ & & \\
\hline \multicolumn{6}{|l|}{ Imunisasi BCG } \\
\hline Ada & $11(22)$ & $36(72)$ & $47(94)$ & - & - \\
\hline Tidak ada & $0(0)$ & $3(6)$ & $3(6)$ & & \\
\hline
\end{tabular}

tidak memiliki risiko yang bermakna $(\mathrm{p}=0,31)$ untuk mengalami infeksi TB dibandingkan dengan anak yang gizi baik. Pada penelitian ini tidak dilakukan penghitungan skoring TB pada subjek penelitian.

\section{Pembahasan}

Pada penelitian ini didapatkan 50 anak yang baru didiagnosis penyakit keganasan hemato-onkologi dengan rentang usia 6 bulan hingga 18 tahun, terbanyak berada pada rentang usia 1-5 tahun 25 (50\%) subjek. Jenis penyakit keganasan yang paling banyak adalah LLA 27 (54\%) subjek. Hal tersebut sesuai dengan American Cancer Society yang menyatakan bahwa leukemia adalah jenis kanker yang tersering pada anak (30\%). Leukemia akut pada masa anak merupakan 30\%-40\% dari keganasan. ${ }^{13,14}$

Jumlah subjek dengan gizi buruk $4(8 \%)$, gizi kurang 20 (40\%), dan gizi baik 26 (52\%) subjek. Hasil tersebut menunjukkan adanya gangguan nutrisi pada pasien dengan keganasan. Penelitian Tazi $\mathrm{dkk}^{15}$ mengenai status nutrisi pada saat anak terdiagnosis penyakit keganasan di Casablanca, melaporkan 33\% anak dengan malnutrisi. Malnutrisi pada pasien dengan kanker dapat berkaitan dengan beberapa faktor, yaitu keganasan itu sendiri, terapi, kondisi sosial ekonomi, intake makanan, energy expanditure, absorbsi nutrien dan metabolisme dan berbagai komplikasi mengenai mukosa oral, maupun saluran cerna yang dapat berpengaruh terhadap status nutrisi pada anak dengan keganasan.

Prevalensi infeksi TB pasien keganasan yang didapatkan berdasarkan uji tuberkulin adalah 11 (22\%) subjek. Angka ini lebih tinggi bila dibandingkan dengan data penelitian Mohammad $\mathrm{dkk}^{1}$ yang mendapatkan 16\% pasien dengan keganasan yang terinfeksi TB berdasarkan hasil uji tuberkulin. Penelitian Lesaca $\mathrm{dkk},{ }^{13}$ mengenai prevalensi infeksi TB dan sakit TB pada anak dengan leukemia di Filipina yang dilakukan pada anak dengan leukemia dalam fase maintenance kemoterapi, mendapatkan hasil rerata infeksi TB yang tinggi $(45 \%)$. 
Uji tuberkulin pertama dilakukan pada 50 subjek, didapatkan hasil uji tuberkulin pertama 4 (8\%) subjek dengan hasil positif dengan ukuran indurasi maksimal $8 \mathrm{~mm}$ (rerata 1,16). Pada subjek dengan hasil positif pada uji tuberkulin pertama tidak dilakukan uji tuberkulin kedua. Uji tuberkulin kedua dilakukan pada 46 subjek dengan hasil positif pada 7 (15\%) dengan ukuran indurasi maksimal 10 mm (rerata 1,46). Terdapat perbedaan kemaknaan antara indurasi pertama dan kedua. Didapatkan peningkatan sensitivitas dua kali uji tuberkulin 175\% dibandingkan dengan satu kali uji tuberkulin dalam mendeteksi infeksi TB. Hal tersebut dapat terjadi karena efek booster yang merupakan peningkatan reaksi uji tuberkulin setelah dilakukan uji tuberkulin ulang. Hasil penelitian ini tidak jauh berbeda dengan penelitian yang dilakukan Mohammad dkk. ${ }^{1}$ Penelitian Mohammad menggunakan dua kali uji tuberkulin pada pasien dengan keganasan. Terdapat peningkatan dari uji tuberkulin yang negatif pada uji pertama menjadi positif pada uji tuberkulin kedua. Pada uji tuberkulin pertama didapatkan hasil positif $2(4 \%)$ subjek dan pada uji tuberkulin kedua didapatkan hasil positif $8(16 \%)$ subjek. ${ }^{16-18}$

Gejala klinis sakit $\mathrm{TB}$, seperti demam lebih dari 2 minggu, batuk lebih dari 3 minggu, adanya riwayat kontak dengan penderita TB aktif, status gizi, serta gambaran radiologis sugestif $\mathrm{TB}$ dihubungkan dengan angka kejadian infeksi TB pada anak dengan keganasan. ${ }^{1,2,18,21}$ Disimpulkan bahwa terdapat hubungan antara gambaran radiologis sugestif $\mathrm{TB}$, riwayat kontak $\mathrm{TB}$, demam 2 minggu atau lebih, batuk 3 minggu atau lebih dengan kejadian infeksi TB. Sementara untuk status gizi tidak ada hubungan dengan infeksi TB. Hasil tersebut berbeda bila dibandingkan dengan penelitian Lesaca $\mathrm{dkk}^{13}$ mengenai infeksi TB pada anak dengan LLA. Lesaca melaporkan bahwa tidak ada hubungan antara hasil postif tes tuberkulin dengan infeksi berulang, lingkungan rumah yang padat, kontak TB, vaksin BCG, wasting dan stunting. Pada penelitian Mohammad $\mathrm{dkk}^{1}$ dilaporkan subjek dengan riwayat kontak TB memiliki proporsi infeksi TB yang lebih tinggi pada pasien kanker. Pada penelitian Triasih, ${ }^{18}$ pada anak yang tinggal serumah dengan kontak TB aktif, didapatkan hasil $47 \%$ anak dengan hasil uji tuberkulin positif.

Terdapat 47 subjek yang mendapatkan imunisasi BCG. Semua subjek mendapatkan imunisasi BCG pada usia kurang dari 1 tahun. Di antara 47 subjek yang mendapatkan imunisasi BCG, terdapat 3 subjek yang tidak terbentuk skar BCG. Pengaruh BCG terhadap reaksi positif tuberkulin secara bertahap akan semakin berkurang dengan berjalannya waktu dan paling lama berlangsung hingga 5 tahun setelah penyuntikan. Pemberian vaksinasi BCG yang diberikan saat bayi akan memberikan efek yang sangat kecil terhadap kemungkinan terjadinya positif palsu pada uji tuberkulin. Pemberian vaksinasi BCG setelah usia lebih dari 1 tahun dapat memengaruhi reaksi uji tuberkulin menjadi lebih besar. Pada penelitian Lesaca $\mathrm{dkk},{ }^{13}$ mengenai infeksi TB pada anak dengan LLA, dilaporkan tidak ada hubungan antara hasil positif tes tuberkulin dengan pemberian vaksinasi BCG. Berdasarkan hasil penelitian, 5 subjek dengan hasil indurasi $\geq 5 \mathrm{~mm}$ berada di rentang usia 0-5 tahun. Hasil positif pada anak di usia ini bisa dipengaruhi vaksinasi BCG. ${ }^{1,19,20}$

Pada 11 subjek dengan hasil indurasi $\geq 5 \mathrm{~mm}, 5$ subjek di antaranya telah mendapat kemoterapi dan atau steroid dan 6 subjek belum mendapat kemoterapi maupun steroid. Kelima subjek ini rata-rata baru satu kali mendapat kemoterapi dan mendapatkan steroid selama satu minggu. Pada 11 subjek dengan infeksi TB, 5 orang telah mendapatkan kemoterapi dan atau steroid yang secara teoritis dapat berpengaruh terhadap ukuran indurasi uji tuberkulin. Meskipun telah mendapatkan steroid dan atau kemoterapi, reaksi terhadap uji tuberkulin masih dapat timbul. Beberapa obat kemoterapi saat ini digunakan juga sebagai terapi imunosupresan untuk penyakit autoimun berat. Obat kemoterapi tersebut, di antaranya siklofosfamid dan metotrexat yang merusak proliferasi dan fungsi efektor dari sel T perifer. Pemberian glukokortikoid dapat menekan produksi dari sitokin pro-inflamatory dan kemokin. Glukokortikoid juga menyebabkan penurunan sel T, menekan perkembangan sel $T$ helper $1.21,22$

\section{Kesimpulan}

Uji tuberkulin pertama didapatkan hasil positif pada 4 (8\%) subjek dan uji tuberkulin kedua didapatkan hasil positif pada $7(15 \%)$ subjek. Dua kali uji tuberkulin pada pasien keganasan dengan rentang waktu 2-4 minggu akan meningkatkan sensitivitas uji tuberkulin $175 \%$ dibandingkan dengan satu kali uji tuberkulin dalam mendeteksi infeksi TB. 


\section{Daftar pustaka}

1. Mohammad, Esmal M, Abdelfatah M, Soliman W. Comparison of the 2-step tuberculin skin test and quantiferon- $\mathrm{Tb}$ gold in- tube test in the screening of latent tuberculosis infection in cancer patients. Egypt: Faculty of Medicine Minia University; 2015.

2. Rahajoe N, Basir D, Makmuri, Kartasasmita B. Pedoman nasional tuberkulosis anak. Edisi ke-2. Jakarta: UKK Respirologi PP Ikatan Dokter Anak Indonesia; 2008.

3. Rahajoe, dkk. Petunjuk teknis manajemen TB Anak. Jakarta: Direktorat Jenderal Pengendalian Penyakit dan Penyehatan Lingkungan Kementrian Kesehatan Republik Indonesia; 2016

4. Kamboj M, Sepkowitz K. The risk of tuberculosis in patients with cancer. New York: Infectious Disease Service Memorial Sloan- Kettering Cancer Centre; 2006 .h.1592-5

5. Hadir A, Mahallawy E, Somia AE, Nefisa GR, Ayman ES, Soheir AE, dkk. Tuberculosis in cancer patients: Role of newer techniques in relation to conventional diagnosis methods. J Advanced Res 2010;1:157-62.

6. Lardizabal A and Reichman L. Diagnosis of laten tuberculosis infection. Dalam: Schlossberg D, penyunting. Tuberculosis and non-tuberculous Mycobacterial infection. Edisi ke-5. New York: McGraw-Hill; 2006. h. 61-70.

7. Ministry of Health New Zealand. Guidelines for tuberculosis Control in New Zealand. Dalam: Diagnosis and treatment of latent tuberculosis infection. Wellington: Ministry of Health New Zealand; 2010.

8. Menzies D. Interpretation of repeated tuberculin test. Am J Respir Crit Care Med 1999;159:15-21.

9. Arwin AP, Julius Roma, Nia Kurniati. Penyakit defisiensi imun buku ajar alergi-imunologi anak. Jakarta: Badan Penerbit IDAI;2007.h.313-32 .

10. Health and Human Services Centers for Disease Control and Prevention. Latent tuberculosis infection: a guide for primary health care providers. Diakses pada: 10 Februari 2018. Didapat dari: https://www.cdc.gov/tb/publications/ltbi/ pdfttargetedltbi.pdf.

11. Spring A, Katherine, Creek T. Two-Step Mantoux testing. Center for disease control. Edisi ke-10. The Australian Immunization Handbook; 2014.h. 413.

12. Salehzadeh F, Arshi S, Habibzadeh. Tuberculin Skin Test (PPD) and its conversion After one year in school children. Int J Trop Med 2009;4:37-40

13. Lesaca MY, Lazarte MD. The prevalence of $\mathrm{Tb}$ infection and disease among children with acute leukemia. J PIDSP 2009; $10: 1-8$

14. Permono HB, Sutaryo, Ugrasena, Windiastuti E, Abdulsalam M. Leukemia akut. Dalam: Buku ajar hematologi-onkologi anak. Jakarta: Badan Penerbit IDAI; 2005.h.236-47.

15. Tazi I, Hidane Z, Zafad S, Harif M, Benchekroun S, Raul Ribeiro R. Nutritional status at diagnosis of children with malignancies in Casablanca. Casablanca: Hematology an Pediatric Oncology Department, Hospital Morocco; 2008.h.16.

16. Trajman A, Steffen RE, Menzies D. Interferon-gamma release assays versus tuberculin skin testing for the diagnosis of latent tuberculosis infection: an interview of the evidence. Pulm Med 2013;2013:601737. doi: 10.1155/2013/601737.

17. Frieden TR. TB Elimination: tuberculin skin testing. Center for disease control and prevention. Diakses pada 10 Februari 2018. Didapat dari: https://www.cdc.gov/tb/publications/ factsheets/testing/skintestresults_revised.pdf

18. Nevita, Retno Sutomo, Rina Triasih. Faktor risiko kejadian sakit tuberkulosis pada anak yang kontak serumah dengan penderita tuberkulosis dewasa. Sari Pediatri 2014;16:5-10.

19. Burl S, Adetifa UJ, Cox M, Touray E, Whittle H, McShane H. The tuberculin skin test (TST affected by recent BCG vaccination but not by exposure of non-tuberculosis Mycobacteria (NTM) during early life. Plos One 2010;5:e12287. https://doi. org/10.1371/journal.pone.0012287.

20. Dowling J, Levy O. Ontogeny of early life immunity. Trends Immunol 2014;35:299-310.doi: 10.1016/j.it.2014.04.007.

21. Agarwal S, Kumar Das S, Agarwal GG, Srivastava R. Steroids decrease prevalence of positive tuberculin skin test in rheumatoid arthritis : implications on antiTNF therapies. Interdisciplinary Perspectives on Infect Dis 2014, Article ID 430134, 5 pages http://dx.doi. org/10.1155/2014/430134.

22. Matarollo S, Sherene Loi, Helene Duret, Yuting Ma, Laurence Zitvogel, Mark J. Smyth. Pivotal role of innate and adaptaive immunity in anthracycline chemotherapy of established tumors. Am Assoc for Cancer Res 2011 DOI: 10.1158/00085472.CAN-11-0753. 